\title{
Studies on University Chinese Teaching Content Optimization Based on Applied Talent Cultivation
}

\author{
Shuhong Sun \\ Changchun Vocational Institute of Technology,Changchun, China \\ sunshuhongcc@126.com
}

Keywords: Higher vocational colleges; Applied-type; University Chinese; Teaching content; Optimization

\begin{abstract}
Setting university Chinese courses in higher vocational colleges is of its significance and value. However, due to realistic predicaments, teaching contents must be reformed based on the cultivation objectives of higher vocational education. This article focuses on elaborating the principle, existing problems and optimization strategies of teaching content selection.
\end{abstract}

\section{Introduction}

Higher vocational education as an important component of China's higher education aims at the cultivation goals as follows: to cultivate advanced technology applied talents who can adapt to the requirements of China's socialist modernization, master basic theory and expertiserequired by the specialty, own comprehensive quality and vocational ability for specialty actual work, and work in the front lines of production, construction, management, and service. Different from the theory-type and design-type talents cultivated in ordinary higher education, it is also different from the skilled talents in secondary vocational education. We set up university language courses in higher vocational education for the purpose of adapting to the national requirements of cultivating talents, fostering humanistic spirits, and improving comprehensive vocational abilities, which requires to combine with reading ability, practical application ability, and cultural quality matching the talent objective. stand up. Therefore, teaching content should focus on the cultivation objectives of higher vocational education so as to highlight its features and construct a Chinese teaching framework with the characteristics of vocational education.

\section{Principles to follow during selection of university Chinese teaching content}

\subsection{In accordance to college students' cognition}

University Chinese with its own unique knowledge framework system and ability training system, as well as its distinctive characteristics and discipline characteristics requires to conform to university Chinese subject features, but also to follow college students' cognition principle when choosing university Chinese teaching content. When choosing university language curriculum content, we should pay attention to college students' analysis and observation capability, logical memory ability, knowledge understanding competence, and other characteristics, but also should focus on the formation of college students' self-consciousness, and the gradual stability of their life value, the world outlook, ideals, beliefs, interest, hobbies, and other psychological features and cognitive characteristics ${ }^{[1]}$. Based on this, we can choose key issues, hot topics, focus issues with large thinking capacity and a large amount of information, and choose course contentwhich can reflect noble ideals, morality, sentiment, personality and entrepreneurial spirit, profoundly manifest the history and reality of social life, show sincere thoughts and feelings, aesthetic taste, and bring aesthetic pleasure and enlightenment to college students.

\subsection{Combine application with effectiveness}

When choosing university language curriculum content, apart from some classic literary works, 
it is necessary to appropriately choose necessary logic knowledge, Chinese knowledge, practical writing knowledge and necessary oral training knowledge. A good mastery of logical knowledge can accurately express college students' own cognition of the objective world to get clear concept, accurate judgment, logic reasoning, and persuasive argumentation ${ }^{[2]}$. A good mastery of Chinese grammar can help students to express in a structured and organized way in clear and idiomatic sentences and words. Good application of rhetoric knowledge can help students to write articles vividly with distinctive features and lively language. Familiarity with practical writing skills can help students to better carry out written ideas communication, exchange of information, solve problems, deal with matters. With a good oral expression ability, students can adequately explain their own views and opinions by choosing the right way according to different occasions, so as to obtain other people's understanding and trust.

\subsection{Keep pace with the times}

University language course content for cultivating students' humanistic quality education should face up to the popular culture context of globalization and re-integrate in line with the principle of keeping pace with the times. It is the life of university Chinese course to pursue the spirit of the times, and to breathe and share fate with the times. Traditional classics and essays must be selected, and excellent works created in the process of advancing bravely with the times must be included. It is necessary to analyze and interpret classical aesthetics from the perspective of the times. For college students' understanding and apperception of the wisdom and life of their predecessors, teachers must excavate the theme of the era in the text. Teachers must provide theoretical cultural interpretation of social issues and phenomena so as to cultivate students' ability to rationally look at various social phenomena. If students can do these things, the time issue of university language course will be solved ${ }^{[3]}$.

\section{Existing problems in vocational university Chinese teaching content}

\subsection{There shows obvious bias in the knowledge structure of university Chinese}

Contents are completely dominated by ancient literature at university stage, reasons for which are multiple including the textbook editors' understanding of the university Chinese, problems of textbook editors' knowledge background, and university Chinese course setting habit. A variety of factors jointly created the current knowledge framework dominated by ancient literature ${ }^{[4]}$. The knowledge framework with its rationality can students to improve their ability to use and understand ancient Chinese, and can establish cultural identity of Chinese traditional culture by learning ancient Chinese prose. However, this framework with great limitation has ignored studies of modern Chinese, contemporary Chinese literature, foreign literature and other knowledge, and neglects the cultivation of students' listening, speaking and writing abilities.

\subsection{Serious lack of pragmatics training in contemporary Chinese teaching content design}

There are dual goals of humanity and instrumentality in Chinese language education. The humanistic goal and instrumental goal are both set in In the middle school stage. At the university level, humanistic goal completely replaced the instrumental goal. It is hard to find the specific pragmatic training module in university Chinese teaching contents. The reality is that regardless of textbook selection or the reconstruction of teaching materials, training of students' pragmatic competence has been ignored in university Chinese teaching with the sole aim of achieving humanistic goal.

\subsection{There is no basis for the conversion of teaching materials to teaching content}

In college Chinese classes, text explanation completely depends on the academic background and personal abilities of the teacher. Most university Chinese teachers graduating from Chinese major tend to have a cognition and understanding of university Chinese from the perspective of the department of Chinese language and literature. As a result, college language classes are more like Chinese major professional classes. Some colleges have even replace college language class with 
the class of literary history, and directly turn the class of Chinese accomplishment in non-Chinese major to classes of literary research and language study. Teachers without sufficient abilities will convert the university Chinese class into high school Chinese class. Teachers with a professional background in the Chinese language will take the university Chinese class into Chinese professional courses. After all, the text is just the carrier. The goal of the conversion should be the improvement of the students' Chinese literacy. Text conversion should meet the requirements of Chinese teaching goal $^{[5]}$.

\section{University Chinese teaching content optimization strategies based on applied talent cultivation}

\subsection{Choose teaching materials with scientific compilation style and content}

The university Chinese teachers in each major can choose suitable teaching materials according to the professional characteristics of the higher vocational majors they teach. The teaching contents of the university Chinese course include contents in three aspects: language, text, and literature, which are the most basic aspects of university Chinese contents. At the same time, it is necessary to take into consideration the part of skill training such as practical writing and oral expression, and reasonably arrange the content and proportion. Regarding how to determine the teaching content of higher vocational Chinese language when compiling teaching materials and teaching, it indeed requires each Chinese language educator to attentively know the object of higher vocational Chinese teaching and the reality of higher vocational education, and make careful choices. Only in this way, our higher vocational education Chinese teaching materials can be recognized by teachers and students. Our teaching can obtain good results.

\subsection{Teaching contents synchronize with social development and reflect the characteristics of the times}

Modern higher vocational education aims at cultivating high-quality modern applied talents. Chinese teaching in higher vocational colleges must keep up with the times, continuously update and optimize the teaching contents, and vitalize classroom teaching with the atmosphere of the times and the spirit of reform. Teaching contents in sync with the modern civilization and in harmony with the social reality can attract students' interest. Furthermore, modern college students with many sources of information and active thinking do not like changeless teaching content. They are more likely to accept new things. Thus, it is particularly important that teaching contents advance with the times which can help students to broaden their horizons, guide students to establish horizontal connections between the university Chinese and disciplines in realistic society, and to know and understand the life and the world. Meanwhile, university Chinese teaching contents in higher vocational colleges should adapt to the students' Chinese knowledge and appreciation level ${ }^{[6]}$.

\subsection{Compile university Chinese textbooks for higher vocational colleges according to students in different majors}

With the accelerating development of the times and refined social labor division, the modern society is not only in need of professional talents but also versatile talents. While vocational college students learn well in their majors, they must also learn some useful knowledge for work and study. Graduates of different majors will face up to different environment after stepping into the society. If we can select the works or people's deeds related to a certain specialty into the teaching materials for students to learn and experience, the results will be more effective.

\section{Conclusion}

University Chinese in higher vocational colleges is an important course. For good effectiveness in this course, content section of teaching materials is priority among priorities. There still exist some deficiencies of university Chinese course in university education, thus needing reform and 
improvement. Therefore, in the process of course positioning and content construction, it is necessary to combine the education level of the school and the actual situation of the students for reasonable setting and teaching of university Chinese course so as to further improve the positive effect of university Chinese on students.

\section{References}

[1] Guo Haijun. Goal and Content Orientation of University Chinese Teaching [J].Journal of Changsha Civil Administration Institute, 2012, (01).

[2] Luo Wenping.Current Status and Cause Analysis of Chinese Education in Higher Vocational Colleges [J].Journal of Liaoning Education Administration Institute, 2008(10).

[3] Guo Chunman. Construct University Chinese Teaching Contentfrom the Perspective of Practicality and Effectiveness [J]. Journal of Daqing Normal University, 2009.4.

[4] Zhou Linna. Parallel implementation of "Language" and "Literature": A Preliminary Study on University Chinese Teaching Content Reform [J].Journal of Shenyang Institute of Aeronautical Engineering, 2012.6.

[5] Liu Liu. Construction of University Chinese Course Teaching Content System [J]. Education Review, 2010.2.

[6] Cui Jun. University curriculum reform based on CultivatingInnovative Talents: Concept Updating and Thinking Selection [J]. China University Teaching, 2009, (4):38- 40. 